\title{
II: IMPeRial AND Colonial Sublime: The Aesthe tics of INFRASTRUCTURES
}

For travelers like Chavchavadze in the 1860 s, still indebted to Romantic aesthetics of his interlocutors, the political antinomies of the geopoetics of the Dariel crossing through the Caucasus are figured primarily by natural features of the sublime landscape, Mount Kazbek and the Terek River (a Romantic discourse which I have called an "Aesopian discourse of nature"). By contrast, staunchly "realist" writers and ethnographers about the same region in the 1880s would have no patience for the hybrid, personified allegorical natural landscape of Romanticism; for these writers, the reality of the Russian state is always figured first and foremost by a cultural feature of the landscape, the Georgian military road, the single connection between the Russian Empire and Georgia through these mountains. ${ }^{1}$ The aesthetic generational sea change from Romanticism to realism in this period can be summarized by the way natural features of the landscape (Mount Kazbek, the Terek River) cede their pride of place to cultural features of the landscape (the Russian road) in Georgian writings about the Dariel crossing. At the same time, we move from a veiled Aesopian critique of politics through the aesthetics of nature to a much more direct, unveiled critique of Russian imperial politics through the aesthetics of its hitherto invisible takenfor-granted infrastructure.

Because of the Russian road passing through it, the region of Xevi differs from other mountain regions in that it is not isolated either from the Russian state or the eyes of passing members of Georgian reading society. Being the only major passage between Russia and Georgia, it can be assumed that most members of the Georgian public will have encountered it at least once. ${ }^{2}$ The paradox of Xevi is that it is the mountainous region that members of educated society will have the greatest firsthand familiarity with, and yet the greatest factual ignorance of, as Moxevian writer Aleksandre Qazbegi points out at the beginning of his ethnography of the region: 
From every district of our country voices come and are printed in newspapers; every district is involved in our common life and is keeping us informed of its happiness and distress. Only one small part of our country, called 'Xevi', is missing from the harmony of this common life. It is indeed true, that from every corner comes correspondence after correspondence, article after article is printed, but about 'Xevi' you might see somewhere two lines or so written, because who cares about Xevi? Who knows about them, or to whom are they interesting, that they bother themselves for their sake? We are so unaware of the people who live in Xevi and their situation, that the greater part of reading society thinks that Xevi is part of Ossetia and its inhabitants are Ossetians. Such ignorance is very surprising about our Moxevians, who are pure Georgians and know no other language than Georgian, even though they are surrounded by people of other tribes.

This circumstance is all the more surprising, because Xevi is located by virtue of its own situation in such a place, where a great military road, which unites our land to the whole of Russia, goes straight through the middle of villages and therefore there hardly remains such a man who knows how to read and write, who, at least once, would not have passed through these places. . . . They have gone through, come back through yet again, Moxevians have many times taken different travelers back and forth in the mountains in the harsh winter, but these [travelers] quickly forgot the service and the help received from those in the mountains. ${ }^{3}$

Unlike more distant Georgian mountain regions like Svaneti and Xevsureti, the hand of the Russian state is omnipresent in Xevi. The historical experience, therefore, of the state is quite different viewed from Xevi than it is from elsewhere in the Georgian Caucasus. So far from being the sublime wilderness so oft-described by Romantic travelers, the landscape of the crossing is a "second nature," a nature completely transformed at the hands of the Russian state: 
Whoever has gone or come through Xevi has without a doubt noticed these barren, skin and bone mountains, which tower in their immensity and are almost lost in the spaces of the sky. The greater part of these places once were covered with beautiful trees, giving Moxevians sufficient resources in life; but, ravaged by the boundless logging by the people and cut down for strategic reasons, they are now completely destroyed and instead of beautiful dense forests there remains only naked mountains. ${ }^{4}$

In Xevi, therefore, we find a privileged place to engage with the Russian state, both in terms of the cultural order of infrastructure, but also the way this order has transformed the indigenous cultural and natural order to become part of this infrastructure.

\section{On the Road, Again: The Critical Aesthetics of Infrastructure}

Romantic descriptions of the Dariel pass present an image of sublime nature, dominated by the Terek River, which serves as a natural figure for indigenous resistance. Against such a worthy sublime natural adversary, the victory of the cultural order of the Russian imperial mission can be figured as being equally sublime. By contrast, in "realist" period descriptions the cultural order, specifically the Russian military highway, is the dominant figure; the natural landscape is a "second nature" produced by strategic deforestation, in essence an extension of the infrastructure of the road itself. As the natural landscape has been transformed, so is the social landscape; while other Georgian mountaineer groups like the nearby Xevsurs tolerate occasional incursions of armed officials of the Russian state, the Moxevian social order has long since been completely transformed by Russian colonialism. Like most mountaineers, lacking any native aristocracy to speak of, Moxevians are alone of Georgian groups of their area in having a local lineage of Russian-appointed service nobles, the Qazbegi family, Aleksandre Qazbegi's own family (Le Galcher Baron 1993), and the (Ossetian and Georgian) peasants who live along the road have been drafted into innumerable forms of corvee labor associated with it, including serving as yamshchiks carrying post and travelers for hire along the road. 
In Romantic descriptions, including to some extent that of Chavchavadze, the road is an often invisible infrastructural position from which the sublime natural landscape can be surveyed, but for the Moxevians and for the aesthetics of realist authors, the material reality of the Russian state and their own predicament is always figured first and foremost by the road itself. The Georgian military road, the construction of which was begun by General Ermolov at the behest of the tsar in the wake of their Russian annexation of Georgia in 1801, was only nominally finished in 1817 . However, work continued on the road until 1863 , at which point the bill stood at a staggering sum of four million pounds (in that period), the resulting road (at a period when such roads were otherwise nonexistent elsewhere in Russia and the Transcaucasus alike) was compared to the Simplon road in the Alps. The construction and maintenance of the strategically vital post road and attendant communications presented unique problems to the Russian imperial postal network (Bazilevich 1999[1927], 84-6), since it required not merely the building of infrastructure of the road and bridges and numerous postal stations, but also the pacification of the countryside (including strategic deforestation) and military garrisons. Travel over this road took days with military escort (including cannons) in the period of Pushkin (1829). Travelers in this period often made use of the "opportunity" afforded by the military escort provided to the mail and joined their carriages to the mail convoy (Bazilevich 1999[1927], 86). By the time of Lermontov, however, the passage was (1840) already becoming a trivial affair, the technological improvements in the road and the military pacification of the countryside turning the passage through Dariel from a sublime crossing into an utterly prosaic one. As if to illustrate the aesthetic changes in the natural landscape wrought by infrastructural improvement, in the first paragraph of the first chapter of A Hero of Our Time (1840), Lermontov has his narrator lose his travel notes about the crossing (Lermontov 1983 [1840], 5). This fortunate misfortune allows him to dispense with "descriptions of mountains, meaningless exclamations of rapture, depictions of scenery which convey nothing, and statistics which no one would ever read," noting merely that he "lunched at Kazbek, had tea at Lars, and was in Vladikavkaz in time for dinner."

British Georgianist Oliver Wardrop, in his account of the road in 1888 , notes both the role of natural actors (the rivers which carved the passage the road would follow through the mountains) and state 
actors in producing the Georgian military road (Wardrop 1888, 34-6). Indeed Wardrop goes so far as to suggest that if Lermontov could dispense with a lengthy description of the Dariel passage, this was not merely a sign that the passage had become an utterly hackneyed literary trope, but that the passage itself had, by his time, become entirely unremarkable:

The part which rivers have played in the history of civilization is well illustrated by this road. The Aragva, flowing southward from Grudaur [sic, Gudauri], and the Terek, running northward from it, have formed the highway along which countless crowds of Asiatics have penetrated into Europe. Between the two streams, there is a distance of some ten miles, forming a huge but not insurmountable barrier, the virtual removal of which did not take place until our own times. It was General Yermolov who, in 1824, succeeded in making the road practicable for troops of all kinds; but from the poet Puskhin's "Journey to Erzerum" (1829), we learn that there was still room for improvement. The traveler had to go with a convoy of 500 soldiers and a cannon, he dare not lag behind for fear of the mountaineers, provisions and lodgings were scarce and bad, the roads were impassable for carriages, the rate of speed was sometimes only ten miles a day. When we read Pushkin's account, and the one given by Lermontov, in "A Hero of Our Times," we can only ask ourselves, "What was the road like before Yermolov?"

During the wars with Kasi-mullah and Shamil, it became indispensable to effect great improvements, and, at length, about five-and-twenty years ago, under the governorship of Prince Bariatinskii, the road was finished, and is now one of the finest in the world, besides being one of the highest-the Simplon is only 6147 feet above sea-level, while the Dariel road is nearly 2000 feet higher. The total distance from Tiflis to Vladikavkaz is 126 miles, and the distance can be done comfortably in less than twenty hours. During the summer 1150 horses are kept 
in readiness at the stations, in the winter the number is reduced by about 300 . Two stage coaches start from each end every day, but as they run during the night also, much of the beauty of the scenery is lost by those who avail themselves of this mode of conveyance; besides, it is difficult to get an outside seat unless you book it a long time in advance. It is far better to travel by troika, as you are then free to stop when you like and as long as you like, and you get an uninterrupted view of the country through which you pass. (Wardrop 1888, 34-6)

By the time of Lermontov (1840) and certainly by the time of Chavchavadze, the road and attendant infrastructure (such as post stations) has become almost invisible (on the invisibility of infrastructure, see Star 1999, Robbins 2007, Larkin 2008, 245). The Russian road longer battles with the Terek River as it did in the Romantic days of Griboyedov and Pushkin. ${ }^{5}$ After the pacification of the mountaineers, too, this military road is presented as being part of an essentially economic sphere of circulation. Chavchavadze's travel letters made some references to the economic predicaments of the Moxevian, and here the road is introduced as a possible solution to the economic hardship of the Moxevians (and the Armenian shopkeeper the source of impoverishment, illustrating once again Chavchavadze's noted Armenophobia). Ghunia explains to Chavchavadze the predicament represented by the road:

'This big road will give you help.'

'What difference does a road make! It's only of use to him who has things bought or made himself to carry and sell.'

'Then you do not hire yourself out?'

'Why would we not? Of course we do.'

'Then you get money from hire.'

'We get it. It doesn't stay in the pocket, though; a Moxevian mountaineer is the prey of the Armenian. There's no food and drink in the house; what we earn goes to the dukan. (VI)

But Chavchavadze's brief account of the economic role of the road 
in the impoverishment of those who dwelt by it was itself subject to revision in the realist writings of the 1880s. In a striking reprise of Chavchavadze's journey through Xevi in his Letters of a Traveler, Aleksandre Qazbegi (1880) invites us to follow a Moxevian peasant like Lelt Ghunia, who works by hire on the road, on a peasant's eye view of the same journey found in Chavchavadze's Letters of a Traveler. Like the road itself, the region of Xevi and the Moxevians themselves represent so much taken-for-granted, seen-but-unnoticed aspects of the landscape of the crossing that they have been, in a sense, like the road itself, relegated to the presupposed and invisible category of infrastructure (Star 1999). An important difference between the accounts is that Qazbegi shows us that economic poverty occurs at the hands of state agents, and not economic agents like the Armenians.

Whoever looks at these places instantly notices, that there the land must not be rich with various plants and the inhabitants cannot only survive with only ploughing and sowing: therefore they must find some other means to keep themselves. Among other things, one of the means is to go between Vladikavkaz and Tbilisi for hire.

Of course, this work, as a means for life, is a great mercy of god for Moxevians; but if you knew how many disasters accompany this labor you would be amazed, as to how in the world Moxevians go on hire and having lost energy they don't give up everything and banish themselves somewhere?!! 6

The problems faced by the Moxevian according to Qazbegi begin before any money is actually made by hire, whereas for Chavchavadze's Lelt Ghunia, the problem is what happens to the money after it is made. Seemingly a trivial point, but leading to very different objects of critique. Whereas Chavchavadze turns on his favorite enemies, the Armenians, Qazbegi covers the journey of the Moxevian to Tbilisi in some detail (just as he would do later in his recollections of life as a shepherd, Qazbegi was perhaps the only true Georgian narodnik, forsaking his family's tradition of service, he instead spent ten years of his life as a shepherd [Le Galcher Baron 1993]), finding corrupt and coercive agents of the Russian state, arbitrary imposts, fines and theft, in his way every step 
along the way. The result is that not only do cart drivers not make any money from the road in the first place, but they often even end up in debt! This is a very different image from that depicted by Chavchavadze: here the road enriches agents of the Russian state, not Armenian shopkeepers.

And certainly, it follows that since the state is omnipresent in the life of Xevi as well, an ethnographic picture of Xevi is impossible without the state, and indeed, an ethnography of Xevi is to a greater extent than anywhere else in the same breath an ethnography of the state. The intensity of contact between the Moxevians and the Russian state is guaranteed by their strategic location along the Georgian military road, not merely corruption of local Georgian go-betweens but also endless requirements of corvee labor, requisitions, bribes, and billeting of soldiers in the region, something not experienced, for example, in more out-of-the-way regions. It stands to reason, therefore, that Qazbegi's ethnography of the Moxevians (1880) should dwell for seven chapters on relations between the Moxevian peasant and the state, before he turns in a few final chapters to matters of "everyday life" that might be considered a few years later to be the province of "ethnography" proper. A comparison with the nearly contemporary ethnographic writings of mountain ethnographer Urbneli (a pseudonym of N. Xizanashvili [1940]) writing about the neighboring Xevsurs is instructive: Urbneli can concern himself almost exclusively with the indigenous forms of polity and everyday life of the Xevsurs, because the Russian state is still not the ubiquitous presence in everyday life there that it is in Xevi.

Part of the reason for this was that the Georgian military road infrastructure was a vital link in the Russian imperial postal network, a system which not only carried the post, but provided essentially all transportation and communication services (including passenger services and for most of the period, the telegraph as well) (Bazilevich 1999 [1927], Prigara 1981 [1941]). The corvee labor for Moxevian and Ossetian inhabitants of the Dariel region, for example, includes both road maintenance, billeting of soldiers, but also postal-carrying duties along this vital link in the Russian imperial postal network, explaining, perhaps, why as far south as Ardahan "Ossetian" is synonymous with "post rider" (yamshchik, postal carriers usually working as part of obligated service who could also carry passengers for a fee, as with Chavchavadze above). Because their homes are along this vital road, the Ossetians 
(and the Moxevians) become subsumed as human parts of the Caucasus postal infrastructure (for a discussion of the role of yamshchik in the Russian imperial post and the forms of exploitation they were subjected to, see Bazilevich 1999 [1927], 35-38; for the role of yamshchiki in providing transport for passengers via the postal network, see Bazilevich 1999 [1927], 45-61).

\section{"Life" and the Road: From Anthropomorphic Nature to Anthropomophizing the State}

How very different does the journey from Vladikavkaz to Tbilisi look when viewed not from the perspective of Chavchavadze but from the perspective of someone like Lelt Ghunia. This "deromanticization" and de-aestheticization of the journey, turning our attention from the sublime landscape (which itself turns out to be a second nature created through deforestation in tandem with the road) to the abject life of the inhabitants, typifies Qazbegi's writings, both his early ethnographies and the later short stories and novels for which he is most famous, but the critique of the colonial aesthetics of Dariel can be taken further. The typical traveler in Xevi, from Griboyedov to Chavchavadze, treats the landscape of Xevi as an aestheticized natural landscape, viewed from the neutral, almost invisible position of the road. But what if we were to turn this formulation on its head; what does the road look like when viewed from the landscape?

The mountain ethnographer Urbneli (N. Xizanashvili), known primarily for his ethnographic writings beginning in the 1880s about the neighboring Pshavs and Xevsurs (collected in Xizanashvili 1940), himself reprises the same literary aesthetic oppositions between Romanticism and realism in explicit form in a feuilleton of 1883 entitled "Notes of a Traveler." The aestheticized description of nature in Dariel, Urbneli supposes, will be familiar to all readers, and he argues that this aestheticized view created by Romanticized "descriptions of nature" prevent understanding the realities of "life":

Everywhere and always there is the description of the beauty of nature. Our homeland attracts travelers more for the loveliness and beauty of its nature. . . Take, for example, Russia's poets, Lermontov, Pushkin . . . it's all 
the description of the beauty of nature and its inhabitants, it's all 'pure art' and rarely the truth and reality of life. ... This is why Europe looks at Georgia primarily from an aesthetic perspective, and this is also why the contents of our life remains uninvestigated, unknown to others. $^{7}$

The blame is laid on all, even Georgian poets "from the great to the 'microscopic'," have participated in the aesthetic alignment of Georgia with "beauty" at the expense of understanding "life." But the "nature" which is the object of Romanticism is not true nature; the Romanticized appropriation of nature in the gorge is in itself a "second nature," identified with human artifice or "art" (xelovneba) and genres of "poetry" (poezia), distinct from and inferior to the true "nature" that is the object of realism, a positivist de-aestheticized nature which is identified with descriptions of "life" (see below, chapter 7).

Thus far, Urbneli has somewhat predictably chosen the most aestheticized stretch of landscape in Georgia as a point of departure to champion a realist aesthetics of utility and "life" against a Romantic reduction of Georgia to (natural) "beauty" (a shorthand for all aesthetic categories typical of Romanticism, including the sublime). He will not be satisfied with a hybrid Aesopianism used by Chavchavadze to mobilize Romantic aestheticized nature as a way of talking about society and politics. Rather, he wants to draw attention away from the nonhuman world of nature (Romantic "beauty") as a veiled representation of the human order and gaze directly on the human world with a realistic aesthetics privileging human "life."

Having debunked the aesthetics of beauty which takes the traveler's imagination away from social life to the natural landscape, his gaze is free to return to the "life" of Xevi. He briefly entertains, and then dismisses, the idea that a traveler could find out about the "life" of Xevi simply by learning the ethnographic lifeways of the local inhabitants: "The identity of the inhabitants, their circumstances and fate we cannot easily learn about. This would require a different kind of research and, well, where would a traveler have time for that?" No, Urbneli's account requires a double inversion of perspective, not merely moving from Romantic descriptions of nature to a realist description of "life," but also, instead of looking at the landscape and locals from the perspective of 
the travelers on the road, to look at the travelers on the road from the perspective of the locals. What does the road look like, and the beautiful carriages of the travelers on it, for example, from the perspective of a Moxevian peasant standing at the side of the road or working on it? The resulting aesthetic vision is one of jarring material contradiction:

'Do they give you money, boy?' I asked one Moxevian. 'Yes, but ...' He fell silent, broke off his answer. And really—all this immense expense, all these beautiful buildings for travelers, elegant hotels and at the same time this shocking poverty of those dwelling by the Aragvi River and the Moxevians, of the inhabitants of this beautiful region, doesn't all this destroy the harmony of the soul and heart, doesn't it upset you? ... Comedy and tragedy-with these two words is expressed the life of our mountain-dwellers. ${ }^{8}$

And what if we take our eyes off the sublime beauty of the landscape, and even take our eyes off the tragic and abject circumstances of the locals and consider the travelers themselves, what do we see?

The road [itself] is different, roads are the veins and arteries of the state, as one old economist said. This, from one perspective, is correct. Yes, this Georgian military road too-is an artery of the Russian Empire and if you want to sense the strength and might of this empire, keep an eye on the travelers [along it]. Here military personnel are constantly moving, various chinovniks [bureaucrats]; rarely do we encounter an ordinary person, a merchant, a tradesman. Why? Because, in my opinion, that the whole life of Russia for the most part is based on military force and on bureaucracy. ${ }^{9}$

If the nature of the "life" of the local inhabitants is not visible to travelers from the road, then the nature of the "life" of the Russian Empire is certainly visible by considering the travelers on the road themselves. The circulation of the Russian road is not the civilizing circulation of le doux commerce, but the circulation of empire. Having 
banished anthropomorphic metaphors from the aesthetics of nature, Urbneli reintroduces them in the aesthetics of empire, using the mixed metaphor of circulation which conflates physiology with infrastructure (Schivelbusch 1977, 194-5). The Russian road is now an organic extension (veins and arteries) of an anthropomorphized empire; to sense the "life" and strength of this empire, one can test the pulse of its exposed artery in Dariel. Urbneli finishes his letter on the antitheses, aesthetic, economic, and political that present themselves in concentrated visible form in this narrow artery of empire, with a conversation with a fellow traveler on the road.

'Our entire life represents [a series of] antitheses,' I told one of my traveling companions-a doctor. 'You are a doctor and you try to save people from untimely death. So many officers, however, are born precisely [sc. to bring untimely death] to others. How much money goes on both state doctors and armies. The doctor has one task, the army has another. But they try to convince us that "they have one general task". What do you say to that?'

'You are still young. Then what power will subdue these savage people, if not the army?' The doctor answered me wrathfully. 'If not bureaucrats, then who will protect the law?' he added. I fell silent. ${ }^{10}$

As Urbneli points out, one of the key antitheses of Xevi is that while the ethnographic study of the "life" of the inhabitants along this road is difficult, the military road is probably the best place in the empire to apprehend the "life" of the Russian state. Though he does not call it that, since as a realist he is interested in a complete de-aestheticization of the heavily Romanticized landscape, we nevertheless see in Urbneli's account a version of the sublime transferred from the natural order to the human order, what could be called with some justice a rhetoric of the "imperial sublime." 11 But this is a sublime where the lyric subject does not seek identification with the imperial conqueror but with the terrified or prostrated imperial subject, and one where the objective locus of the sublime is not the greatness of sublime nature, but the sublime of the Russian state represented by the circulation on the Russian road itself. 


\section{Imperial and Colonial Sublime}

In earlier Romantic articulations of the imperial sublime, the enraptured poet appropriates the sublime aesthetics of nature to frame, among many other possible things, a sublime reading of the empire, in part "as an attempt on the part of the Russian writer as lyric subject to establish a relationship (sometimes celebratory, sometimes mutedly critical) with the state" (Harsha Ram, personal communication). For Ram and Shatirishvili (2004, 13, see Ram 1998, 2003, Manning 2008 for other readings), "The Russian imperial sublime . . . involved two axes, a vertical axis provided in the "romantic period by the alpine landscape, and a horizontal axis created by the panoramic stretch of conquered territory that was viewed from a height by the enraptured lyric subject." Here, the imperial sublime projects the vastness of empire onto vertical and horizontal axes. The enraptured lyric subject of the imperial sublime often seeks identification with a greater power, imperial power embodied in the monarch, set in opposition to a largely dehumanized sublime nature, so that the rhetoric of the imperial sublime is one in which the empire attracts the sublime properties of the sublime nature it conquers.

The sublime nature of the Caucasus, embodied in different ways Mount Kazbek or the rushing, roaring Terek, represent for Russian travelers on the road the beauty and savagery of the Caucasus, and in the same breath, the "imperial sublime" of the vast and powerful Russian Empire that has conquered it. By contrast, for Urbneli, it is the Russian road itself, and specifically the nature of the traffic (state agents) on the road, that represents the "imperial sublime" of the Russian Empire, one viewed, however, not from the perspective of the conqueror but the conquered.

In this sense, Urbneli's confrontation with the Russian road bears a certain resemblance to what Larkin (2008) has termed "the colonial sublime," in which the colonizing power shows "the terrifying ability to remake landscapes and to force the natural world to conform to these technological projects by leveling mountains, flooding villages, and remaking cities; these were the ways in which the sublime was produced as a necessary spectacle of colonial rule" (Larkin 2008, 36). The colonial sublime is first of all a version of the technological sublime (Marx 1964, Nye 1996) which moves the prototypical object of the sublime from 
the sphere of nature to the sphere of culture and technology. Second, this is a sublime which, unlike the imperial sublime, does not so much emphasize the greatness of the sublime object as the abjection of the lyric subjects feel in the presence of such an object: "Here the sublime is experienced not so much through a sense of absolute greatness but through the overwhelming physical powerlessness individuals feel in the face of something overpowering and terrible" (Larkin 2008, 36). Unlike the imperial sublime, where the lyric subject seeks identification with the monarch surveying his vast dominion from a dizzying height, the colonial sublime interpellates the colonized subject, using technology both to incite awe and perhaps terror, but also to "proffer technology as a mode of development" so that the sublime aspect of technology will become domesticated and ultimately be taken for granted as part of colonial modernity (Larkin 2008, 36-7).

For Urbneli and Qazbegi, however, as critical realists, the "colonial sublime" of the Russian road contains only the first moment, the ability to incite awe and terror in the face of the power of the Russian state. The road lacks the second moment as a mode of civilizational or economic development for those living alongside it. Going far further than Chavchavadze in their critiques of Russian road, and by extension, the Russian Empire as an agent of civilizational progress for the colonized, particularly the mountain tribes of the Caucasus, they instead point up the ways in which the road remains almost exclusively an instrument of empire (see Jersild [1999, 510-11] for similar intelligentsia critiques of Russian technological projects elsewhere in the Caucasus).

The Russian road as an instantiation of the colonial sublime contains other semiotic vulnerabilities to intelligentsia critique as well, namely that, like all forms of the technological sublime, as Larkin points out, it quickly loses its sheen and becomes a taken-for-granted invisible infrastructural aspect of the landscape, or worse, it comes to be received in terms of the aesthetic category of the picturesque as being ruined, dilapidated, backward, and so on: "steamships render sailing ships slow, airplanes destroy steamboats' apparent speed, and jets make propeller planes anachronistic, nostalgic emblems of a previous era. ... When [the] idea of the sublime is tied to the representation of colonial power it builds in a fragility that forever haunts its efforts" (Larkin 2008, 248). The Russian colonial sublime has the added vulnerability that these newer versions of the technological sublime are always already 
at hand somewhere else, Russian infrastructure will always suffer from invidious comparison with a European model; to compare the Dariel road across the Caucasus to the European Simplon road across the Alps seems like a compliment, taking the comparison of the natural sublime (Alps=Caucasus) to the technological sublime (Simplon=Dariel), but it is also a potential statement of backwardness, of derivativeness. As Harsha Ram (personal communication) notes, the difference between the imperial sublime, "which exists chiefly for the rulers and the ruling elite" and the colonial sublime is fundamentally temporal; "while the imperial sublime is related to the increasingly anachronistic ancient regime, the 'colonial sublime,' in using technology, is future-oriented. Ironically, it also becomes anachronistic, but through the inevitable obsolescence of technology."

The British colonial sublime discussed by Larkin takes advantage of a binary geopoetics so that the technological sublime can represent European civilization to the benighted colonies. However, in a ternary system in which Russian state both represents the colonized with respect to Europe and the colonizer with respect to the colonized people, the colonial sublime becomes even more unstable. ${ }^{12}$ The voice of the local intelligentsia steps in here as elsewhere as a mediating figure: on the one hand, the intelligentsia is already familiar with these new European technologies and can readily compare the Russian version to its European or North American models that they have read about and find them wanting; on the other hand, the intelligentsia can stand with the state in contemplating the unenlightened "Oriental" peasantry's irrational animistic response to the technological sublime. Thus, even at the moment the railroad from Poti to Tbilisi is sparkling new (1872), an intelligentsia commentator finds that it is already slow, calculating its average speed as twenty to twenty-five versts an hour (about 21-26 $\mathrm{km}$ an hour, about the speed of a galloping horse). It is slow, then, not compared to anything else available in the Caucasus except perhaps the fabulous speed of a boat ride down the Choroxi River (on which below). It is slow compared to things one can read about in newspapers, for example, the "wondrous speed" of American and English railways, and "in Russia too, you can't find one railroad which still on average doesn't exceed 35-45 versts in an hour." ${ }^{13}$ Having thus geopoetically divided this technological object into truly sublime Euro-American, not-so-sublime Russian, and not-at-all sublime Caucasus versions, the commentator is 
content to continue this strategy of damning with faint praise by noting that the local versions excel over the Russian versions in comfortable appointments of the interior, that a second-class cabin in the Caucasus is almost better than a first-class cabin in Russia.

The intelligentsia as mediating figure between colonizer and colonized, state and people, can simultaneously inhabit both sides of the colonial sublime, like the Georgian Romantics in their appropriation of the natural sublime (Ram and Shatirishvili 2004, Manning 2008). The Georgian intelligentsia, contemplating a new Russian railroad, can not only prove their coevality with European civilization by knowing what is, and what is not, a good candidate for awe, but also by adopting the stance of the colonial civilizers themselves in bemused contemplation of the imagined stupefaction and superstition of "our simple people" at these animated iron monsters (compare Bektas [2001], Larkin [2008, 40-43], on similar narratives imputing animism and credulity to Oriental or African audiences when faced with Western technological "wonders"):

When the people do not understand the real explanation of a phenomenon or an object, then they try to explain it in their own peculiar way. Who knows what our simple people are saying about this railroad. Some say, 'some sort of evil spirit sits in this mashina [machine, the author is voicing the peasant's words] and it makes the wheels roll with its hands'; some say 'the anglichans [sc. the English] have captured a dragon and imprisoned it in the front room and it propels the train, and when it encounters difficulties, its shrieks and screams become more frequent.' And who knows what others say, how they explain the movement of the railroad! ${ }^{14}$

The mediating intelligentsia position is also a critical position. Taking advantage of the semiotic vulnerability of the colonial sublime, which when working properly can at best aspire to becoming an invisible order of infrastructure, travelers like Chavchavadze, especially his imagined French fellow traveler, would seek to minimize or defang this "technological sublime" by focusing on more typically picturesque elements: stereotypically picturesque figures like antiquated post carts and draw attention away from the technological sublime to what one could 
call the dilapidated, backward, ruinous "technological picturesque."15 By realigning the technological order of the Russian Empire with the technological picturesque as opposed to the technological sublime, such critiques could make powerful charges of Russian backwardness and consequent inability to embody civilization, which is then located elsewhere, in France or Britain.

And indeed, the infrastructure Russian postal system in the Dariel pass, upon which all travelers depend for transport, there as elsewhere provides a set of picturesque images of technological backwardness in the form of yamshchiki and Russian postal carts. On the technological level, since the yam or relay system upon which it was based always used local populations, local domesticated animals (horses, reindeers dogs, camels, etc.), and indigenous technological affordances (a picturesque assortment of carts, boats, sleds, and so forth) adapted to local conditions, the varied climates, landscapes, and conditions of the vast empire, it could not help but present itself as a picturesque assemblage of varied transport methods and technologies (Bazilevich 1999 [1927], 14, 67-88, 173). The passage through the Caucasus was certainly an exemplary picturesque spot within a network characterized by its technologically picturesque qualities (Bazilevich 1999 [1927], 84-88). Only in those portions of the network where steamship or train could be used could the system aspire to "technological sublime," and these links could always be found wanting by comparison with their American or European models and in any case could not displace the more "picturesque" local technologies of the relay system everywhere, particularly not in the Dariel passing (Bazilevich 1999 [1927], 172-189).

For example, Chavchavadze's Letters of a Traveler dwells on the Russian postal cart and yamshchik, primarily to allow him to critique Russia's pretensions to representing a civilizing colonial power (he brings in a Frenchman only to make fun of Russia's post carts!):

When I had packed, that is, when I had put my little leather knapsack in the cart, I turned to bid farewell to my newly made French acquaintance.

'Who invented this vehicle?' He asked, pointing to the postcart on which the sleepy 'yamshchik' was stupidly dozing.

'The Russians', I answered. 
'I imagine nobody is likely to dispute the honor with them. I pity you to be forced to addle your brain and shake up your stomach on a thing like that.'

'No harm done. If the whole of Russia travels like this, why should I complain?'

'They all travel like that? That's why they have gone so far! God give you a safe journey. As for me, I tell you frankly I would not risk my life by getting into it. Good bye! If we meet again some day I beg you to remember me.'

With these words he gave me his hand to bid farewell and grasped it firmly as only a European can.

I entered the postcart. (I)

Similarly, the Russian officer's delusional imagining of a Russian technological sublime in which flies become the engines of progress replacing the expensive machines of the French is introduced to underline the same opposition between the European technological sublime and the laughable Russian technological picturesque or even grotesque.

The French invent devilish sorts of things like that, but to buy their machines is dear, while my invention doesn't cost a farthing. What expense is there in catching two flies and putting them in a box? It is nothing. But now, see what will be the result of my invention: when it spreads perhaps there will be a trade in flies. There will thus be a new form of commerce in the land; some fine day you will go into your town and you will find a fly shop. That's not bad. How many hungry mouths may be filled by the help of flies! What are flies at present? Nothing. Of what use are they? None at all. Now you see of what great significance the labor and work of a learned and wise man is to the land. (III)

For critical writers about the Caucasus of the 1880s, like Qazbegi and Urbneli, the imperial sublime, as viewed from the perspective of the conquered, was one terrifying in its aspect and consequences and could not be so simply defanged by one laughing Frenchman or one laughable 
Russian scientific officer. These "mountain writers" then, are somewhat exceptional compared to the rest of the Georgian intelligentsia in the fierceness of their critiques of the Russian civilizing mission, emphasizing the terrifying forceful aspect of the imperial sublime over the progressive potentialities of the colonial sublime in their assessment of the Russian road as a proxy for more general critiques of the savagery of the Russian military conquest of the "savage tribes" of the Caucasus (on which, see Layton 1994, 1997; Jersild 2002, Manning 2009). They thus emphasize one aspect of the more general ambivalent reception of the narrative of Russian colonial rule that characterized "native" intelligentsia elsewhere in the Caucasus, in which the savagery of Russian conquest of the Caucasus was complemented by its civilizing mission elsewhere (Khalid 1997, 1998; but see Jersild 1999 for native intelligentsia ambivalence about this aspect of the Russian civilizing mission as well).

Many non-Russians in the Russian Empire were active members of imperial educated society (obshchestvo), and they often conceived of the colonial advance of Russia as part of the march of the progressive West and "civilization" itself into the backward lands of the East. Reformist empire builders who criticized the brutal wars and population transfers that marked the conquest of the southern border lands also emphasized the civilizing mission of the empire on its eastern frontier. (Jersild 1999, 503)

\section{Conclusion: The Antinomies of Intelligentsia Discourse}

"Our entire life represents antitheses," Urbneli tells his traveling companion. The antitheses that become visible in miniature form over this short stretch of land, in Dariel, are the same antitheses that haunt not only the Russian Empire, but the subaltern culture of circulation being created by the Georgian intelligentsia culture of circulation through this period. ${ }^{16}$ Into each antithesis, Europe and Asia, civilization and savagery, the Russian Road and the Terek River, the state and the people, the intelligentsia inserts itself as a mediating voice. Beginning with Chavchavadze, the Georgian intelligentsia in the Dariel finds the 
geographic object, Georgia, as a thing already spoken about, and so the Dariel pass becomes a privileged place as well as topos to engage all that was said before about Georgia as a whole. By the 1880s, this marginal area of Georgia in the Caucasus becomes the privileged place both to critique Russian imperial rule as well as to imagine a sublime ethnographic vision of Georgianness, the Georgians of the mountains, once considered savages, now imagined as surrogate selves whose freedoms make their communities an imagined "elsewhere" which Georgians can enjoy vicariously (again, following earlier Russian narratives of escape and vicarious identification with the mountaineer freedom of the Caucasus (Layton 1994, Ram 1999, Grant 2009, Manning 2009). By the 1890s, a reviewer of the works of Aleksandre Qazbegi could look back on his work as a new direction within Georgian realism characteristic of the 1880s, one which involved applying the principles of realism both to the ethnographic study of the life of Georgian mountain peoples (the topic with which Qazbegi began) and the simultaneous elaboration of the ethnographic life of these people in literary treatments (which Qazbegi turned his hands to after he finished his Mokhevian ethnographies). ${ }^{17}$

This new direction is the study of our mountain people, their customs, adats, beliefs, ideals, poetry. This direction also has another side, that is, our poets and belletrists have turned the life of these people into themes for the practice of their own talents. ${ }^{18}$

To understand this "turn to the mountains" of the 1880s, we need to understand what happened in the decade between the publication of Chavchavadze's letters (1861-1871) and Aleksandre Qazbegi's first writings about the Moxevians (1880). The intervening period is the moment of the development and consolidation of a specifically Georgian print culture in 1860s-1870s in the newspaper Droeba. In this period, the mountains play a minor role; it is West Georgia and especially the newly conquered regions of Ottoman Georgia in the late 1870s that forms the critical borderlands in which the mediating voice of the intelligentsia forms itself. This period is defined by two main events: the emancipation of the serfs (announced for the empire in 1861, beginning in East Georgia in 1864, and continuing from 1865 to 1871 in West 
Georgia) and the conquest of Ottoman Georgia (1878-9). Especially in the latter case, it might be argued that a radical disconfirmation of the happy fairytale reunification of the Georgian people, the disappointment of intelligentsia projects to mediate this divide between "Ottoman Georgia" and "European Georgia," evidenced first and foremost by the massive flight of Ottoman people from Russian rule (and their Georgian intelligentsia mediators), was what caused the subsequent immense boom of interest in the mountains of Georgia in the 1880s. The central intelligentsia project of the period to mediate between the lettered public of the intelligentsia and the unlettered voice of the people, that forms the core of Chavchavadze's text, encountered in the borderlands of Ottoman and European Georgia a transcribable, but unassimilable people and landscape. In Ottoman Georgia, Georgian intelligentsia moved from being "Orientals" in relation to Russia (as they are in Letters of a Traveler) to being "Europeans" in relation to the recently conquered population of "Ottoman Georgia." The recalcitrant realities of Ottoman Georgia which exploded the myths the intelligentsia had written for it made it a place unfit for the free play of the imagination, which then shifted into the mountains of Georgia, a place that Russian Romantics had already made into a fitting home for the imagination.

The story of an imagined Georgia which begins with Chavchavadze at the northern boundaries of Georgia in the Dariel pass ends at the southern boundaries not a decade later in the empty Ottoman town of Ardanuji with a correspondent writing under the pseudonym of $S$. Bavreli. After that, the Georgian imagination in the 1880s turns away from the southern borders back to the Caucasus. In between, the antinomies of this central text are reconstituted in the unfamiliar landscape of Ottoman Georgia. The next chapters tell that story, unfolding the categories of Georgian print culture as they emerge in this period in the context of this fateful encounter of European Georgia with its Oriental other. 


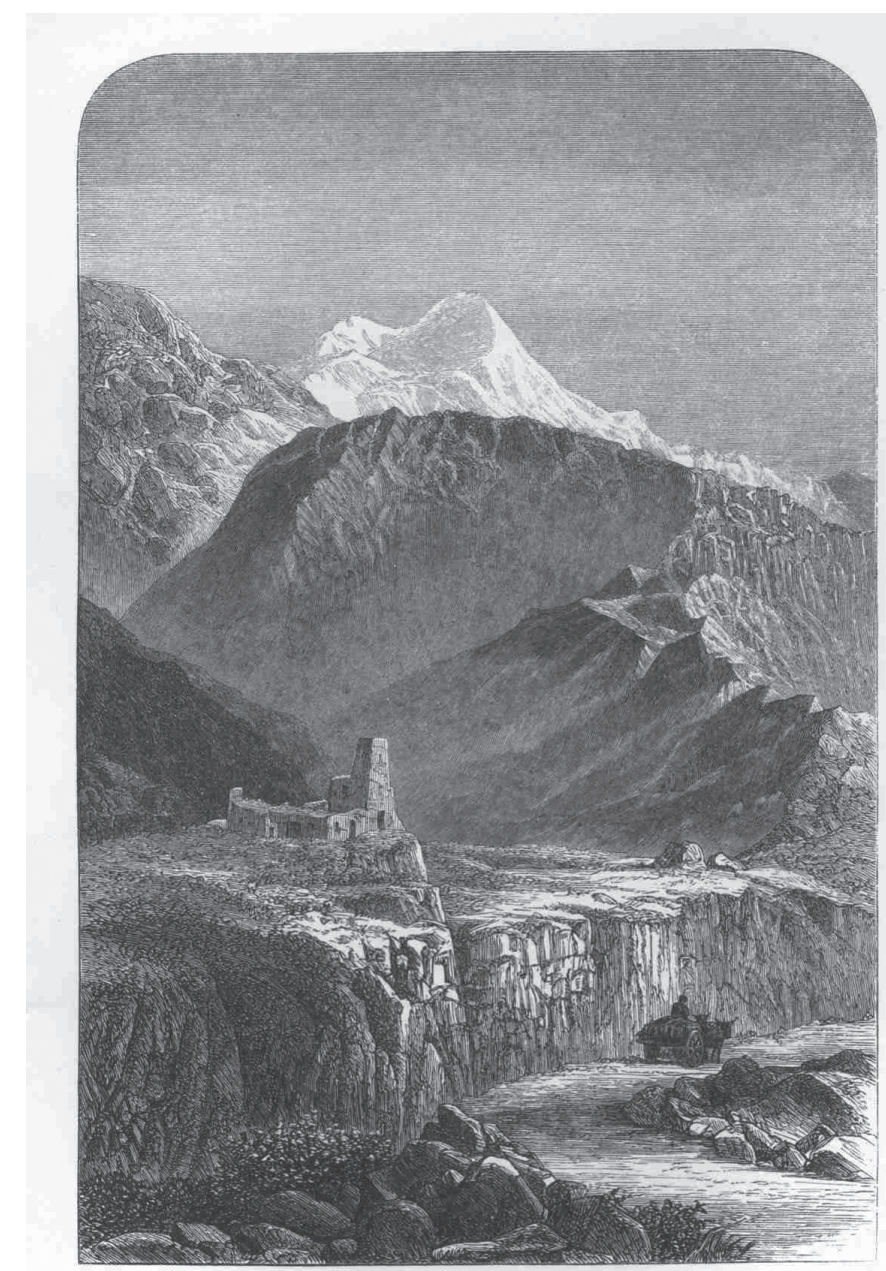

KAZBEK, FROM THE SOUTH.

(from Freshfield 1869, facing p. 197)

Figure 4: Picturesque Technology and Sublime Nature on the Dariel Pass. 